\title{
Uptake and distribution of copper in the freshwater crab Potamonautes perlatus (Crustacea) in the Eerste River, South Africa
}

\author{
R.G. Snyman, A.J. Reinecke* \& J.A.J. Nel \\ Department of Zoology, Stellenbosch University, Matieland, 7602 South Africa \\ Received 1 April 2001. Accepted 16 November 2001
}

\begin{abstract}
The uptake and distribution of copper in the freshwater crab Potamonautes perlatus in the Eerste River, South Africa, were studied seasonally by comparing copper concentrations in crabs, water and sediment at two localities, one upstream and one downstream from the town of Stellenbosch. Copper concentrations were determined by atomic absorption spectrophotometry in whole crabs of different size classes as well as in various organs and tissues. The digestive gland contained the highest concentration of copper (mean 29.9, range $1.9-74.1 \mu \mathrm{g} / \mathrm{g}$ wet mass) irrespective of season, when compared to other tissues. No differences in total sediment (range 1.2-13.5 $\mu \mathrm{g} / \mathrm{g}$ ) or water (range 0.01-0.2 $\mu \mathrm{g} / \mathrm{g}$ ) copper concentrations were found between the two localities. An influence of anthropogenic activities between the localities on the sediment and water levels of copper could not be detected. Smaller crabs accumulated more copper per unit mass than larger crabs with all crabs having significantly higher concentrations than both water and sediment. Higher copper concentrations per unit mass in whole crabs from the downstream locality indicated that environmental conditions at this locality may have favoured uptake since total copper concentrations both in water and sediments did not differ significantly between the two localities. $P$. perlatus may therefore still be utilized in biomonitoring studies, not necessarily to reflect prevailing environmental concentrations, since copper can also be regulated, but to assess exposure to and bioavailibility of copper.
\end{abstract}

Key words: heavy metal accumulation, digestive gland, biomonitoring.

\section{INTRODUCTION}

Freshwater ecosystems in southern Africa are under increasing threat due to a rapidly expanding human population. Rivers are very vulnerable since waste in effluents from point sources and other contaminants from industries, homes and farms reach them either directly through spraydrift or runoff (Robinson \& Avenant-Oldewage 1997; Schulz et al. 2001) or through groundwater seepage. Heavy metals can enter the food chain through air, water, soil and organisms and are derived from industrial effluents, agricultural runoff, mining and mineral processing, stormwater runoff, natural erosion of bedrock, and atmospheric transport. In aquatic environments, $\mathrm{Cu}$ can occur in particulate, colloidal and soluble form and speciation of $\mathrm{Cu}$ is influenced by physico-chemical, hydrodynamic and biological factors (Moore \& Ramamoorthy 1984). Although it is an essential trace element, it can also pose a threat to freshwater ecosystems because of its toxicity to aquatic organisms,

*Author for correspondence. E-mail: ajr@maties.sun.ac.za especially invertebrates and algae.

Concern has been raised about the environmental levels of $\mathrm{Cu}$ in the vicinity of the Eerste River which runs through vineyards before reaching the town of Stellenbosch in the Western Cape, South Africa. The fungicide copper oxychloride is used in vineyards for extended periods during the spraying season (Snyman et al. 2000; Helling et al. 2000). It is used as a broad-range fungicide at an application rate of $1.25-7.5 \mathrm{~kg} / \mathrm{ha}$, with several applications per season (Krause et al. 1996). Relatively high levels of $\mathrm{Cu}$ have been determined in vineyards in the region. Snyman (2000) found mean $\mathrm{Cu}$ concentrations of between 907 and $1592 \mathrm{mg} / \mathrm{kg}$ on vine leaves one week after spraying. This raises questions about contamination levels in groundwater as well as in surface waters and about effects on non-target organisms. Several studies have shown that $\mathrm{Cu}$ can accumulate in freshwater decapods (e.g. Anderson \& Brower 1978; France 1978; Van Eeden \& Schoonbee 1991).

In South Africa, most studies have so far focussed on the freshwater crab Potamonautes warreni and 
not on P. perlatus. The latter species occurs in rivers in the southwestern region of the Western Cape (Barnard 1950) where it plays an important role in the processing of organic material (Hill \& $\mathrm{O}^{\prime}$ Keeffe 1992). P. warreni has been advocated as a species with potential use in biomonitoring and Reinecke et al. (in press) have indicated that $P$. perlatus may be able to play a similar role in assessments of exposure levels and bioavailability of heavy metals. The ecotoxicological relevance of this study is further enhanced by the fact that $P$. perlatus serves as a source of food for various predators, including the Cape clawless otter (Aonyx capensis), water mongoose (Atilax paludinosus) and giant kingfisher (Megaceryle maxima) (Arkel 1979; Purves et al. 1994), as well as various fish species.

The aims of this study were to determine the concentrations of heavy metals in the water and sediment of the Eerste River and to establish whether and to what extent $P$. perlatus accumulates $\mathrm{Cu}$ from the river. The aim was also to investigate the distribution of this metal in various tissues and organs of the crab's body and to measure seasonal changes in body concentrations. By selecting sampling locations in the river both upstream and downstream from the town, the possible influence of human activities could also be taken into account. Data on physical, chemical and bacteriological features were also obtained in order to interpret differences in conditions prevailing at the two localities, which may influence the bioavailability of $\mathrm{Cu}$.

\section{MATERIALS \& METHODS}

The Eerste River rises in the Jonkershoek Valley of the Western Cape in South Africa. It flows through the Jonkershoek Forest Reserve, the Assegaabosch Nature Reserve and several vineyards before reaching the town of Stellenbosch $\left(33^{\circ} 56^{\prime} 10^{\prime \prime} S\right.$, $18^{\circ} 51^{\prime} 34^{\prime \prime} \mathrm{E}$ ). For the rest of its course the river is bordered by agricultural land and small settlements before reaching the sea on the False Bay coast.

One sampling locality was chosen to represent a relatively uncontaminated area upstream of the town and the other downstream from the town where human intervention has taken place. The first locality was situated in the Assegaaibosch Nature Reserve below a small weir $\left(33^{\circ} 58^{\prime} 21^{\prime \prime} \mathrm{S}\right.$, $\left.18^{\circ} 56^{\prime} 4^{\prime \prime} \mathrm{E}\right)$. A part from crab-eating fish species, the giant kingfisher (Megaceryle maxima) was observed frequently during sampling periods. Signs of the Cape clawless otter (Aonyx capensis) in the form of scats and eaten crabs were also observed here. The water mongoose (Atilax paludinosus) also occurs in this area (Purves et al. 1994). The second locality, also below a small weir, was situated downstream from the Adam Tas bridge directly behind a large farmers winery $\left(33^{\circ} 56^{\prime} 47^{\prime \prime} \mathrm{S}, 18^{\circ} 50^{\prime} 32^{\prime \prime} \mathrm{E}\right)$. An otter latrine indicated that these animals utilized this area for foraging. The water at this site was often murky and foul-smelling. Runoff from the Plankenburg River and effluent from a winery seemed to affect the quality of the water at this locality.

Crabs were collected on eight occasions during autumn, winter, spring and summer at both localities from April 1993 to January 1995 covering two years. Large ( $>40 \mathrm{~mm}$ carapace width) and medium-sized individuals (21-40 $\mathrm{mm}$ carapace width) were caught in baited funnel traps set in the afternoons and left overnight, or until a large enough sample $(>10)$ had been obtained. Small crabs $(<21 \mathrm{~mm})$ were caught infrequently in the traps and numbers often had to be supplemented by hand-collecting.

In the laboratory the crabs were frozen, sexed, measured, weighed and grouped into the three size-classes mentioned above. Representatives of each size-class were used for dissection and for measuring whole-body levels of copper. Whole crabs and carapaces were dried at $105-110^{\circ} \mathrm{C}$ for $24 \mathrm{~h}$, ground and pooled to obtain a large enough sample for analysis. Specimens were dissected to remove the digestive gland, gills and claw muscle. Samples were stored at $-10^{\circ} \mathrm{C}$ in acid-rinsed bottles. One gram of each pooled sample (whole crab, carapace or thawed tissue) was weighed and digested in a Labcon dual digester, using a 10:1 ratio of $55 \%$ nitric acid and $70 \%$ perchloric acid (Van Eeden \& Schoonbee 1991). The samples were firstly digested with $10 \mathrm{ml}$ nitric acid for $24 \mathrm{~h}$ at room temperature and thereafter at $40-50{ }^{\circ} \mathrm{C}$ for $2 \mathrm{~h}$, after which the temperature was increased to $140{ }^{\circ} \mathrm{C}$ for one hour. The latter was repeated after adding $1 \mathrm{ml}$ perchloric acid to each sample.

The water samples for metal analysis were collected seasonally over two years at each locality in fast-flowing sections of the river $5-10 \mathrm{~cm}$ below the surface. Sediment samples were collected every season in the top $10 \mathrm{~cm}$ of the river bottom in shallow sections of the river. Water samples were acidified with $55 \%$ nitric acid and filtered through Whatman $9.0 \mathrm{~cm}$ qualitative filter paper as well as a Sartorius Minisart $0.45 \mu \mathrm{m}$ pore size filter using a needle and syringe. Each sample 
was diluted with $100 \mathrm{ml}$ distilled water and kept at $6{ }^{\circ} \mathrm{C}$ until analysed by atomic absorption spectrometry. Sediment samples were prepared for metal analysis by firstly drying the samples at $100^{\circ} \mathrm{C}$ for $24 \mathrm{~h}$, or until the weight stabilized, after which each sample was sieved to obtain a homogeneous sample. These were then ground with a pestle and mortar and a subsample of $1 \mathrm{~g}$ weighed on a Mettler AE200 balance. The filtered sediment samples were digested using a 1:1 ratio of hydrochloric and nitric acid as described by Anderson (1974). Ten $\mathrm{ml} 55 \%$ nitric acid was added to each sample. After $24 \mathrm{~h}$ the temperature was raised to $50^{\circ} \mathrm{C}$ for two hours in a Labcon dual digester. The temperature was then increased to $140^{\circ} \mathrm{C}$ for one hour after which $10 \mathrm{ml} 32 \%$ hydrochloric acid was added and the sample reheated for one hour at $140^{\circ} \mathrm{C}$. The samples were allowed to cool after clear solutions had been obtained.

Clear, cooled samples were filtered through a Whatman no. 9 qualitative filter paper and a Sartorius Minisart $0.45 \mu \mathrm{m}$ pore size filter, using a needle and syringe. The filtrate was diluted to $100 \mathrm{ml}$ with distilled water and stored at $6{ }^{\circ} \mathrm{C}$, awaiting analysis. Spiked samples of sediments as well as muscle tissue showed a mean recovery above $78 \%$. The concentrations of $\mathrm{Cu}$ in crabs and $\mathrm{Cu}, \mathrm{Pb}, \mathrm{Zn}, \mathrm{Cd}$ and $\mathrm{Mn}$ in water and sediments were determined by atomic absorption spectrometry using a Varian AA 250 Plus. Standard solutions from Sigma and de-ionized water were used to prepare the analytical standards. Metal concentrations were expressed as $\mu \mathrm{m}$ metal per gram of wet or dry mass as indicated. Where necessary, concentrations were converted from dry to wet mass for meaningful comparison. The bioconcentration factor $(\mathrm{BCF})$ for $\mathrm{Cu}$ (the ratio between the environmental concentration and the body or specific tissue load) (Van Straalen \& Verkleij 1993) was calculated to provide an indication of this metal's accumulation from water and sediments to crabs.

All other water analysis data, including $\mathrm{pH}$ and conductivity, were obtained from the Department of Water Affairs and Forestry who have several sampling stations in the river. Bacteriological data were provided by the Cape Town Municipality and Regional Services Council.

Statistical analyses of data were done with Quatro Pro 2.0 (Corel Corp, Ottawa) and Statgraphics 1.0 (Manugistics, Rockville, MD). Student's $t$-test was used to compare mean values obtained for the metal concentrations in different compartments, localities or seasonal concentration loads. Statistical analysis for purposes of seasonal comparisons of water and sediment concentrations were not undertaken due to small sample size. Where data sets were not normally distributed, mean logarithm values were used to calculate $t$-values. Where normal distribution could not be obtained, the Mann-Whitney test was performed on the original data. In all cases $P<0.05$ was accepted as level of significance.

\section{RESULTS}

\section{Metals in water and sediment}

The mean water concentrations of $\mathrm{Zn}, \mathrm{Mn}, \mathrm{Cu}$, $\mathrm{Pb}$ and $\mathrm{Cd}$ from the upstream locality did not differ significantly from the downstream locality (Table 1) $(P>0.05$, Student's $t$-test $)(n=8)$. Samples were pooled for all seasons because small sample size precluded meaningful comparison of water and sediment concentrations between seasons. Since only one water and one sediment sample were analysed per locality per season, they only represented a snapshot of concentrations at the time and could not be seen as representative of a particular season since runoff events could change concentrations quickly. The mean $\mathrm{Zn}$ concentration in the sediment of the upstream locality $(77.5 \pm 38.4 \mu \mathrm{g} / \mathrm{g})$ was significantly higher than at the more polluted downstream locality $(44.7 \pm 32.8 \mu \mathrm{g} / \mathrm{g})(P<0.05$, Student's $t$-test $)$ whereas the manganese concentration of the sediment was significantly higher at the upstream locality $(P<0.05$, Student's $t$-test). The mean concentrations of all the other metals did not differ significantly $(P>0.05)$ between the sediments of the two localities (Table 1).

The mean $\mathrm{Cu}$ concentrations in sediments were 7.2 (range 1.4-15.8) and 7.4 (range 3.0-15.0) $\mu \mathrm{g} / \mathrm{g}$ at the upstream and downstream localities respectively. The conductivity, suspended solids, phosphates and coliform counts as reported by the Department of Water Affairs and the Cape Town Municipality and Regional Council were significantly higher at the downstream locality (Table 1). The mean $\mathrm{Cu}$ concentrations in the water samples were consistently below the levels considered by the Department of Water Affairs and Forestry, the Water Research Commission and the Department of Health as 'ideal' for domestic use (Kempster et al. 1980, WRC 1999). The water concentrations are presented in Fig. 1A and the sediment concentrations in Fig. 1B. 
Table 1. Selected physical, chemical and bacteriological features of Eerste River water (w) and sediments (s) collected at Assegaaibosch Nature Reserve (upstream) and near Stellenbosch Farmers Winery (downstream) of the town of Stellenbosch from April 1993 to January 1995. Figures in brackets indicate number of samples.

\begin{tabular}{llll}
\hline & Unit & Upstream & Downstream \\
\hline $\mathrm{pH}(\mathrm{w})$ & $\mathrm{pH}$ & $6.7(26)$ & $7.1^{*}(43)$ \\
Conductivity (w) & $\mathrm{mS} / \mathrm{m}$ & $6.7(24)$ & $18.5^{*}(43)$ \\
Dissolved oxygen & $\mathrm{mg} / \mathrm{l}$ & $10.1(3)$ & $9.0(21)$ \\
Suspended solids (w) & $\mathrm{mg} / \mathrm{l}$ & $7.4(24)$ & $9.1^{*}(43)$ \\
Nitrates & $\mathrm{mg} / \mathrm{l}$ & $0.5((18)$ & $0.3(42)$ \\
Phosphates (w) & $\mathrm{mg} / \mathrm{l}$ & $0.05(18)$ & $0.06^{*}(42)$ \\
Hardness (CaCo $)$ & $\mathrm{mg} / \mathrm{l}$ & $14.5(2)$ & $45.0(3)$ \\
Total coliforms (w) & $100 \mathrm{ml}$ & $128227^{*}(22)$ \\
$\mathrm{Faecal} \mathrm{coliforms} \mathrm{(w)}$ & $100 \mathrm{ml}$ & $198(6)$ & $15347^{*}(22)$ \\
$\mathrm{Mn}(\mathrm{w})$ & $\mathrm{mg} / \mathrm{l}$ & $105(6)$ & $0.13(8)$ \\
$\mathrm{Zn}(\mathrm{w})$ & $\mathrm{mg} / \mathrm{l}$ & $0.14(8)$ & $0.23(8)$ \\
$\mathrm{Cu}(\mathrm{w})$ & $\mathrm{mg} / \mathrm{l}$ & $0.22(8)$ & $0.07(8)$ \\
$\mathrm{Pb}(\mathrm{w})$ & $\mathrm{mg} / \mathrm{l}$ & $0.62(8)$ & $0.04(8)$ \\
$\mathrm{Cd}(\mathrm{w})$ & $\mathrm{mg} / \mathrm{l}$ & $0.27(8)$ & $0.006(8)$ \\
$\mathrm{Mn}(\mathrm{s})$ & $\mu \mathrm{g} / \mathrm{g}$ & $0.006(8)$ & $55.3^{*}(8)$ \\
$\mathrm{Cu}(\mathrm{s})$ & $\mu \mathrm{g} / \mathrm{g}$ & $184.7(8)$ & $7.4(8)$ \\
$\mathrm{Pb}(\mathrm{s})$ & $\mu \mathrm{g} / \mathrm{g}$ & $7.2(8)$ & $7.0(8)$ \\
$\mathrm{Cd}(\mathrm{s})$ & $\mu \mathrm{g} / \mathrm{g}$ & $5.3(8)$ & $0.45(8)$ \\
$\mathrm{Zn}(\mathrm{s})$ & $\mu \mathrm{g} / \mathrm{g}$ & $0.43(8)$ & $77.5^{*}(8)$ \\
\hline $\mathrm{Sin}$ & $44.7(8)$ &
\end{tabular}

*Significantly different between localities, $P<0.05$, Mann-Whitney or Student's $t$-test, as indicated in text.

\section{Copper in crabs}

The crabs showed large individual variation in whole-body, tissue and carapace concentrations of $\mathrm{Cu}$. Pooled data for all seasons showed that whole crabs from the downstream locality $(n=51)$ had significantly higher $(P<0.05$, Mann-Whitney test $)$ mean $\mathrm{Cu}$ concentrations per gram wet mass $(27.6$, range $7.5-200.0 \mu \mathrm{g} / \mathrm{g})$ than the crabs $(n=60)$ from the upstream locality $(15.3$, range $6.6-45.2 \mu \mathrm{g} / \mathrm{g}$ $\mathrm{Cu}$ ). The data for both localities were pooled to determine the general relationship between the body size of crabs and the metal concentrations per gram wet mass of whole crabs (Fig. 2). Carapace widths were compared with $\mathrm{Cu}$ concentrations. A strong negative correlation $(r=-0.58)$ was obtained. Smaller crabs ( $n=6$ and $n=4)$ had progressively higher mean concentrations of $\mathrm{Cu}$ (35.6 and $73.4 \mu \mathrm{g} / \mathrm{g})$ than larger crabs $(n=22$ and $n=6)$ with mean concentrations of 11.1 and $13.5 \mu \mathrm{g} / \mathrm{g}$ respectively for the two localities. Since the logarithmically transformed whole crab data for large, medium-sized and small crabs from each locality failed to provide normal distributions, comparisons of these $\mathrm{Cu}$ concentrations in the various size classes were done by using non-parametric Mann-Whitney tests. These tests showed significant differences $(P<0.05)$ in $\mathrm{Cu}$ concentrations
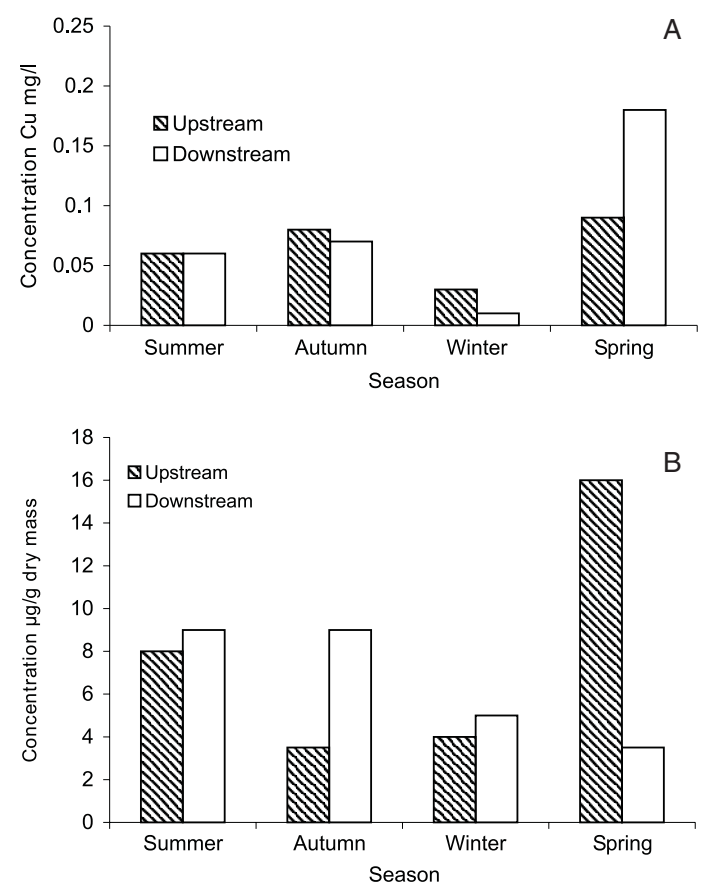

Fig. 1. Mean Cu concentrations $(n=8)$ in $(\mathbf{A})$ water $(\mathrm{mg} / \mathrm{l})$ and (B) sediment ( $\mu \mathrm{g} / \mathrm{g}$, dry mass) of the Eerste River upstream and downstream of Stellenbosch. 
Table 2. Mean copper concentration ( $\mu \mathrm{g} / \mathrm{g}$ wet mass) in the muscles, digestive gland, gills, gonads and carapace of crabs from the Eerste River (both localities pooled).

\begin{tabular}{lrrrc}
\hline & $n$ & Mean & S.D. & Range \\
\hline Muscle & 29 & 18.1 & 34.26 & $0.0-166.32$ \\
Digestive gland $^{*}$ & 33 & 29.95 & 21.42 & $1.9-74.1$ \\
Gonads $_{\text {Gills }}$ & 25 & 18.43 & 43.91 & $1.0-222.2$ \\
Carapace & 26 & 16.99 & 25.93 & $2.56-132.35$ \\
& 39 & 6.78 & 9.12 & $0.0-44.54$ \\
\hline
\end{tabular}

${ }^{*}$ Concentration significantly different $(P<0.05$, Student's $t$-test) from all others.

between medium-sized and small crabs at the more polluted downstream locality and also between large and small crabs.

Comparison of the two localities for the $\mathrm{Cu}$ content of the different size classes, and of the carapace and other tissues revealed no significant differences $(P>0.05$, Student's $t$-test). A comparison of all male crabs $(n=49)$ with all female crabs $(n=40)$ from both localities revealed that males had significantly higher $(P<0.05$, Mann-Whitney test) mean whole-body $\mathrm{Cu}$ concentrations per gram mass $(26.9 \mu \mathrm{g} / \mathrm{g})$ than females $(17.2 \mu \mathrm{g} / \mathrm{g})$.

The mean $\mathrm{Cu}$ concentrations in various tissues of crabs (pooled for both localities and all seasons in order to obtain a general notion of possible accumulation and compartementalization) are presented in Table 2 . The digestive gland samples $(n=$ 33) had the highest mean concentration of $\mathrm{Cu}$ of 29.9 (range 1.9-74.1) $\mu \mathrm{g} / \mathrm{g}$ (wet mass). Significant differences $(P<0.05$, Student's $t$-test $))$ were found between the metal content of the digestive glands

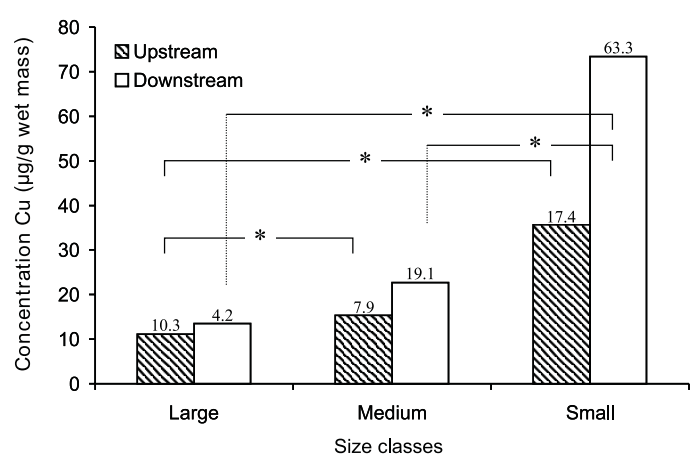

Fig. 2. Mean Cu concentrations per gram wet mass in Potamonautes perlatus whole crabs of various size classes from the upstream and downstream localities in the Eerste River. Figures above columns indicate standard deviations. Upstream: large, $n=22$; medium-sized, $n=34$; small, $n=6$; downstream: large, $n=6$; mediumsized, $n=39$; small, $n=6$. * Significantly different, $P<$ 0.05, Mann-Whitney test. and gonads $(n=25)$, the digestive glands and carapaces ( $n=39$, converted to wet mass for carapaces), the digestive glands and gills $(n=26)$ and the digestive glands and muscles $(n=29)$ (wet mass). The carapaces had the lowest mean concentration (6.8, range $0.0-44.5 \mu \mathrm{g} / \mathrm{g} \mathrm{Cu}$, dry mass). Comparison of the $\mathrm{Cu}$ distribution in the various tissues of crabs from the two localities (Fig. 3) revealed a high variation with no significant differences $(P>0.05$, Student's $t$-test) between the two localities.

A comparison of seasonal differences in the mean $\mathrm{Cu}$ contents per gram mass of whole crabs (Table 3) for pooled data from the two localities, showed that the highest mean concentration occurred in autumn $(30.8 \pm 23.4 \mu \mathrm{g} / \mathrm{g}$, wet mass $)$ and the lowest $(16.8 \pm 6.9 \mu \mathrm{g} / \mathrm{g}$, wet mass) in spring. Based on the Mann-Whitney test, the autumn value differed significantly from those of both spring and summer $(P<0.05)$. Seasonal

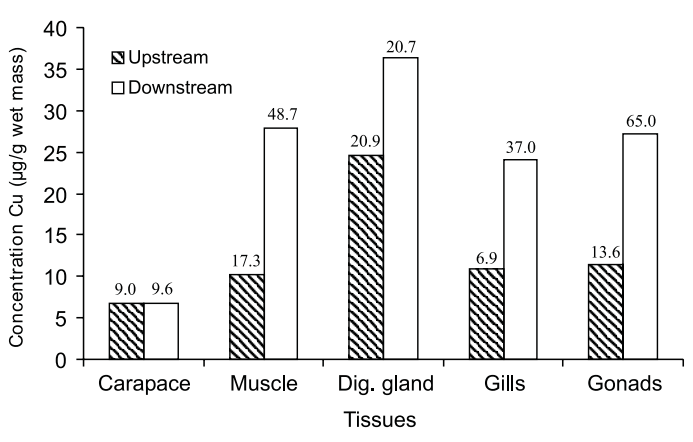

Fig. 3. Mean Cu concentrations per gram (all converted to wet mass) in various tissues and carapace of Potamonautes perlatus in the upstream and downstream localities of the Eerste River. Figures above columns indicate standard deviation. No significant differences $(P>0.05)$ were obtained by comparing individual tissue concentrations between the two localities. (For upstream and downstream localities, respectively: carapace, $n=19$ and 20; muscle, $n=16$ and 13; digestive gland, $n=18$ and 15; gills, $n=14$ and 12; gonads, $n=$ 11 and 14.) 
Table 3. Mean Cu concentration ( $\mu \mathrm{g}$ per gram wet mass, pooled for both localities) in whole crabs from the Eerste River to compare seasonal differences (Mann-Whitney test).

\begin{tabular}{|c|c|c|c|c|c|c|}
\hline & $n$ & Mean & S.D. & Range & $z$-value & $P$-value \\
\hline \multirow{2}{*}{$\begin{array}{l}\text { Summer } \\
\text { Vs } \\
\text { Autumn }\end{array}$} & 49 & 16.52 & 14.02 & $4.64-60.87$ & \multirow[b]{2}{*}{2.825} & \multirow[b]{2}{*}{$<0.05$} \\
\hline & 16 & 30.79 & 23.38 & $10.05-92.3$ & & \\
\hline \multirow{2}{*}{$\begin{array}{l}\text { Summer } \\
\text { VS } \\
\text { Winter }\end{array}$} & 49 & 16.52 & 14.02 & $4.64-60.87$ & \multirow[b]{2}{*}{0.564} & \multirow{2}{*}{$>0.05$} \\
\hline & 21 & 28.78 & 42.97 & $5.37-300.32$ & & \\
\hline \multirow{2}{*}{$\begin{array}{l}\text { Summer } \\
\text { VS } \\
\text { Spring }\end{array}$} & 49 & 16.52 & 14.02 & $4.64-60.87$ & \multirow[b]{2}{*}{1.82} & \multirow[b]{2}{*}{$>0.05$} \\
\hline & 25 & 16.77 & 6.87 & $7.48-31.15$ & & \\
\hline \multirow{2}{*}{$\begin{array}{l}\text { Autumn } \\
\text { vs } \\
\text { Winter }\end{array}$} & 16 & 30.79 & 23.38 & 10.05-92.3 & \multirow{2}{*}{-1.85} & \multirow{2}{*}{$>0.05$} \\
\hline & 21 & 28.78 & 42.97 & $5.37-200.32$ & & \\
\hline \multirow{2}{*}{$\begin{array}{l}\text { Autumn } \\
\text { vs } \\
\text { Spring }\end{array}$} & 16 & 30.79 & 23.38 & 10.05-92.3 & \multirow{2}{*}{-1.99} & \multirow{2}{*}{$<0.05$} \\
\hline & 25 & 16.77 & 6.87 & $7.48-31.05$ & & \\
\hline \multirow{2}{*}{$\begin{array}{l}\text { Winter } \\
\text { VS } \\
\text { Spring }\end{array}$} & 21 & 28.78 & 42.97 & 5.37-200.32 & \multirow{2}{*}{0.13} & \multirow{2}{*}{$>0.05$} \\
\hline & 25 & 16.77 & 6.87 & $7.48-31.15$ & & \\
\hline
\end{tabular}

differences in the concentrations of $\mathrm{Cu}$ in the various organs and tissues also occurred, with the carapace $(12.45 \mu \mathrm{g} / \mathrm{g})$ and gills $(50.3 \mu \mathrm{g} / \mathrm{g})$ having the highest concentrations in autumn. The digestive gland, having the highest mean concentration of all the various tissues analysed of $29.9 \mu \mathrm{g} / \mathrm{g}$, based on the pooled data for all seasons, did not show significant differences $(P<0.05$, MannWhitney test) in $\mathrm{Cu}$ content between the various seasons. The digestive glands of the summer crabs had the highest mean $\mathrm{Cu}$ concentration (39.1 \pm $23 \mu \mathrm{g} / \mathrm{g}$, wet mass, $n=15$ ) and those of the winter crabs the lowest $(15.5 \pm 9.4 \mu \mathrm{g} / \mathrm{g}$, wet mass, $n=6)$.

When comparing the sediment concentrations of $\mathrm{Cu}$ (Table 4) with the concentrations in the various organs and tissues, significant differences $(P<$ 0.05 . Student's $t$-test) were only found between the sediment concentrations and the concentrations in the digestive glands at both localities. The concentration of $\mathrm{Cu}$ was significantly higher in the digestive gland than in the sediment. BCFs values of 4.0 and 5.7 were calculated for the digestive glands from the upstream and downstream locality, respectively (Table 4 ). The $\mathrm{Cu}$ concentrations in whole crab, muscles, digestive glands, gonads, gills and carapace were in all cases significantly higher $(P<0.05$, Student's $t$-test $)$ than the concentrations in the water at both localities. The $\mathrm{BCF}_{\mathrm{w}}$ values (for water) for all tissues (excluding carapaces which were lower and digestive glands which were higher at both localities) were of the same order of magnitude for both localities.

\section{DISCUSSION}

Setting of water quality criteria for heavy metals is notoriously difficult due to the fact that so many variables are involved which may influence bioavailability and uptake. Since we found no statistically significant differences $(n=8)$ in total sediment and water $\mathrm{Cu}$ concentrations upstream and downstream of the town of Stellenbosch, this may indicate that household, industrial or other human related activities did not have a major influence on $\mathrm{Cu}$ concentrations in the river water at the time. Both the water (Fig. 1A) and sediment (Fig. 1B) concentrations of $\mathrm{Cu}$ at the two localities appeared to differ considerably during spring but were based on a very small sample size $(n=2$ per season), prohibiting meaningful inter-seasonal comparisons. The very strong seasonal effects of rainfall events and runoff (Schulz et al. 2001) on chemical concentrations, already shown for Western Cape rivers, may account for occasionally observed differences.

The differences between other parameters of the two localities ( $\mathrm{pH}$, conductivity, suspended solids, phosphates and coliforms) were an indication that runoff or effluents from various sources in and around the town influenced water quality in other respects.

The total sediment concentrations of $\mathrm{Cu}$ were very similar at both localities. The concentrations were significantly higher than the concentrations in the water but lower than the concentrations in the digestive glands of the crabs (Table 4). Little is 
Table 4. Results of Student's $t$-test for differences in mean copper concentrations $(\mu \mathrm{g} / \mathrm{g})$ of the sediments, carapace (converted to wet mass), crab tissues (wet mass) at localities upstream and downstream of Stellenbosch as well as the calculated bioconcentration factors $\left(\mathrm{BCF}_{\mathrm{s}}\right)$. Mean logarithms of copper concentrations were used to calculate the $t$-values (Student's $t$-test).

\begin{tabular}{|c|c|c|c|c|c|c|c|}
\hline & $n$ & Mean & S.D. & Range & $t$ & $P$ & $\mathrm{BCF}_{\mathrm{s}}$ \\
\hline \multicolumn{8}{|l|}{ Upstream } \\
\hline Sediment & 8 & 6.15 & 4.16 & $1.2-13.5$ & & & \\
\hline vs Carapace & 19 & 6.82 & 8.90 & $0.0-34.57$ & 0.48 & $>0.05$ & 1.11 \\
\hline vs Muscle & 16 & 10.24 & 17.26 & $0.0-66.6$ & 0.36 & $>0.05$ & 1.67 \\
\hline vs Digestive gland & 15 & 24.62 & 20.95 & $2.3-74.1$ & -3.66 & $<0.05$ & 4.0 \\
\hline vs Gonads & 11 & 11.53 & 13.61 & $1.0-50.7$ & -0.53 & $>0.05$ & 1.87 \\
\hline \multicolumn{8}{|l|}{ Downstream } \\
\hline Sediment & 8 & 6.35 & 4.06 & $2.56-12.82$ & & & \\
\hline vs Carapace & 20 & 6.75 & 9.55 & $2.02-44.54$ & 0.6 & $>0.05$ & 1.06 \\
\hline vs Muscle & 13 & 27.78 & 46.72 & $0.35-166.32$ & -0.83 & $>0.05$ & 4.37 \\
\hline vs Digestive gland & 15 & 36.33 & 20.87 & $1.9-68.0$ & -4.15 & $<0.05$ & 5.72 \\
\hline vs Gonads & 14 & 27.22 & 65.07 & $1.64-222.2$ & -0.66 & $>0.05$ & 4.29 \\
\hline
\end{tabular}

known about the mobility and desorption of $\mathrm{Cu}$ associated with these sediments and the factors influencing them. It is known that $\mathrm{Cu}$ can be reversibly bound to sediment particles while a portion of the metal in solution is bound to various ligands with only a small fraction of soluble $\mathrm{Cu}$ being present as the free $\mathrm{Cu}^{2+}$ ion species in the solution (Sauve et al. 1997). Since the partitioning of $\mathrm{Cu}$, its solubility and speciation are determined by several factors, including $\mathrm{pH}$, organic acids such as phenols and organic matter, it is conceivable that differences in conditions at the two localities (Table 1) could have influenced $\mathrm{Cu}$ availability for uptake. Although the total environmental $\mathrm{Cu}$ concentrations at the two localities were very similar, many other parameters such as $\mathrm{pH}$ and conductivity (Table 1) did indeed differ which in turn could affect bioavailability and, consequently, uptake and toxicity of $\mathrm{Cu}$ (Förstner \& Prosi 1979; Lewis \& McIntossh 1986). The significant difference in the sediment $\mathrm{Mn}$ and $\mathrm{Zn}$ concentrations between the two localities may also point towards a difference in metal binding of $\mathrm{Cu}$ between the two localities. Previous studies (US Geological Survey 1982) have indicated that the environmental mobility of $\mathrm{Cu}$ can be influenced by levels of other metals competing for binding sites. The significant difference in whole crab concentrations between the two localities (15.36 $\pm 11 \mu \mathrm{g} / \mathrm{g}$ wet mass, $n=60$ at the upstream and $27.6 \pm 31 \mu \mathrm{g} / \mathrm{g}$, wet mass, $n=51$ at the downstream locality) provides evidence that bioavailability of $\mathrm{Cu}$ may have been different at the two localities. Unknown differences in water conditions between the two localities may account for this, with conditions in the more polluted downstream locality probably favouring higher accumulation of $\mathrm{Cu}$.

Benthic organisms can take up metals from the sediment but since clear relationships between total trace metal levels in sediment and inhabiting organisms are seldom found, caution is required in ascribing biomonitoring roles to organisms. Elevated levels of trace metals in crabs can allow for improved chemical analysis, making them useful for biomonitoring purposes (Steenkamp et al 1994). However, deductions about the extent to which these levels reflect environmental contamination at a specific point in time, is not warranted without due consideration of temporal factors and factors governing uptake and elimination. This is especially the case for essential metals such as $\mathrm{Cu}$ which are also physiologically regulated.

Comparison of our data with those of previous studies in the Eerste River (King 1981) indicated that with the exception of an increase in nitrates, probably resulting from agricultural activities, most other parameters remained fairly constant over time. The $\mathrm{Cu}$ concentrations in the sediments from both localities were very similar to those cited for relatively unpolluted estuaries (Watling \& Watling 1983).

The mean $\mathrm{Cu}$ concentrations in whole crabs from the two localities were very similar to concentrations found in P. warreni from a polluted stream (Steenkamp et al. 1994). Individual variation was, however, much greater in P. perlatus and 
included individuals with relatively high $\mathrm{Cu}$ concentrations of up to $200 \mu \mathrm{g} / \mathrm{g}$. The relatively high $\mathrm{BCF}$ values for whole crabs, tissues and carapace at both localities indicate that $\mathrm{Cu}$ was accumulated above environmental levels by $P$. perlatus.

Our study indicated that the digestive gland contained the highest concentrations of $\mathrm{Cu}$ irrespective of seasonal variation in environmental levels. This is in agreement with the findings of Hilmy et al. (1988) for concentrations in Portunis pelagicus and provides further support for the notion that $\mathrm{Cu}$ is primarily regulated in this gland in contrast to non-essential heavy metals such as $\mathrm{Pb}$, which is incorporated largely into the exoskeleton that serves as a storage site (Anderson \& Brower 1978; Reinecke et al., in press).

This study showed that size (and therefore probably also age) could influence uptake and distribution of $\mathrm{Cu}$ in P. perlatus. This finding is in agreement with that of Steenkamp et al. (1994) for $P$. warreni. The higher metabolic rate of smaller/younger crabs could play a role in this regard. Hill \& O' Keeffe (1991) found significant differences in food preferences between large and small individuals of this species. Smaller crabs tended to prey more on aquatic invertebrates whereas the larger crabs preferred plant material. Since various studies have shown that aquatic invertebrates tend to accumulate heavy metals (Albers \& Camardese 1993; Kiffney \& Clements 1993), while plants will do so to a limited extent, accumulation along the invertebrate food chain could provide a plausible explanation for the observed higher metal concentrations in smaller crabs. Small crabs might also consume finelydivided organic particles in the sediment to which metals may be adsorbed. More information on the proportional loads of $\mathrm{Cu}$ in the exoskeleton and other tissues of crabs of different age and size classes and the role of the moulting cycle are needed to explain observed differences. Moulting could be considered a detoxifying mechanism accelerating the output of $\mathrm{Cu}$ accumulated in the carapace (Lopez Greco et al. 2000).

It is concluded from this study that although the water of the Eerste River was relatively unpolluted by $\mathrm{Cu}$ at the time of this survey, the freshwater crab P. perlatus accumulated this metal from the environment, primarily in the digestive gland. The difference in body burdens of crabs between the two localities may be an indication that this species could play a role in monitoring the bioavailability of these metals. However, the influ- ence of seasonality and the high variation in body burdens of individual crabs should be duly considered in order to obtain a more complete picture. We did not find clear evidence of a consistent relationship between seasonal changes in environmental concentrations and seasonal changes in body burdens, probably also reflecting the fact that the crabs can regulate copper levels sufficiently. The highest $\mathrm{Cu}$ concentrations in whole crabs were found during autumn, which coincided with the end of the spraying season of copper oxychloride in the vineyards on the banks of the river. Whether this constitutes a causal relationship between spraying activities and elevated $\mathrm{Cu}$ levels in crabs cannot be concluded from this study and requires further investigation.

\section{ACKNOWLEDGEMENTS}

This study was funded by the National Research Foundation and the University of Stellenbosch.

\section{REFERENCES}

ALBERS, P.H. \& CAMARDESE, M.B. 1993. Effects of acidification on metal accumulation by aquatic plants and invertebrates. Environmental Toxicology and Chemistry 12: 959-976.

ANDERSON, J. 1974. A study of the digestion of sediment by the $\mathrm{HNO}_{3}-\mathrm{H}_{2} \mathrm{SO}_{4}$ and the $\mathrm{HNO}_{3}-\mathrm{HCl}$ procedures. Atomic Absorption Newsletter 13: 31-32.

ANDERSON, R.V. \& BROWER, J.E. 1978. Patterns of trace metal accumulation in crayfish populations. Bulletin of Environmental Contamination and Toxicology 20: 120-127.

ARKEL, G.B.F. 1979. Aspects of the feeding and breeding biology of the giant kingfisher. Ostrich 50: 176-181.

BARNARD, K.H. 1950. Descriptive catalogue of South African decapod Crustacea. Annals of the South African Museum 38: 179-194.

FÖRSTNER, U \& PROSI, F. 1979. Heavy metal pollution in freshwater ecosystems. In: Biological Aspects of Freshwater Pollution, (ed.) O. Ravera, pp. 129-161. Pergamon Press, Oxford.

FRANCE, R.L. 1978. Calcium and trace metal composition of crayfish (Orconectes virilis) in relation to lake acidification. Canadian Journal of Fisheries and Aquatic Science 44: 107-113.

HELLING, B., REINECKE, S.A. \& REINECKE, A.J. 2000. Effects of the fungicide copper oxychloride on the growth and reproduction of Eisenia fetida (Oligochaeta). Ecotoxicology and Environmental Safety 46: 108-116.

HILL, M.P. \& O'KEEFFE, J.H. 1992. Some aspects of the ecology of the freshwater crab (Potamonautes perlatus Milne Edwards) in the upper reaches of the Buffalo river, eastern Cape Province, South Africa. South African Journal of Aquatic Science 18: 42-50.

HILMY, A.M., EL-HAMID, A.B.D. \& GHAZALY, K.S. 1988. Variation in zinc and copper levels with sex and size in different tissues of the crab Portunus pelagus (Linnaeus). Folia Morphologiae 36: 160-166. 
KEMPSTER, P.L., HATTINGH, W.H.J. \& VAN VLIET, H.R. 1980. Summarized water quality criteria. Department of Environmental Affairs Technical Report 108.

KIFFNEY, P.M. \& CLEMENTS, W.H. 1993. Bioaccumulation of heavy metals by benthic invertebrates at the Arkansas River, Colorado. Environmental Toxicology and Chemistry 12: 1507-1517.

KING, J.M. 1981. The distribution of invertebrate communities in a small South African river. Hydrobiologia 83: 43-65.

KRAUSE, M., NEL, A. \& RAMAUTAR, N. 1996. A Guide to the Use of Pesticides and Fungicides in the Republic of South Africa. Plant Protection Research Institute, Department of Agricultural Development, Pretoria.

LÓPEZ GRECO, L.S., BALANOS, J. RODRIQUEZ, E.M., \& HERNÁNDEZ, G. 2000. Survival and molting of the pea crab larvae Tunichotheres moseri Rathbun 1918 (Brachyura, Pinnotheridae) exposed to copper. Archives of Environmental Contamination and Toxicology 40: 505-510.

LEWIS, T.E.\& McINTOSH, A.W. 1986. Uptake of sediment-bound lead and zinc by the freshwater isopod Asellus cummunis at three different $\mathrm{pH}$ levels. Archives of Environmental Contamination and Toxicology 15: 495-504.

MOORE, J.W. \& RAMAMOORTHY, S. 1984. Heavy Metals in Natural Waters. Applied Monitoring and Impact Assessment. Springer-Verlag, New York.

PURVES, M. G., KRUUK, H. \& NEL, J.A.J. 1994. Crabs, Potamonautes perlatus in the diet of otter, Aonyx capensis and water mongoose Atilax paludinosus in a freshwater habitat in South Africa. Zeitschrift für Saügetierkunde 59: 332-341.

REINECKE, A.J., SNYMAN, R.G. \& NEL, J.A.J. 2001. Uptake and distribution of lead $(\mathrm{Pb})$ and cadmium(Cd) in the freshwater crab Potamonautes perlatus in the Eerste River, South Africa. Bulletin of Environmental Contamination and Toxicology (In press).

ROBINSON, J. \& AVENANT-OLDEWAGE, A. 1997. Chromium, copper, iron and manganese bioaccumulation in some organs and tissues of Oreochromis mossambicus from the lower Olifants River, inside the Kruger National Park. Water SA 23: 387-403.
SAUVE, S., McBRIDE, M.B., NORVELL, W.A. \& HENDERSHOT, W.H. 1997. Copper solubility and speciation of in situ contaminated soils: effects of copper level, $\mathrm{pH}$ and organic matter. Water Air Soil Pollution 100: 133-149.

SCHULZ, R., PEALL, S.K.C., DABROWSKI, J.M. \& REINECKE, A.J. 2001. Current use insecticides, phosphates and suspended solids in the Lourens River, Western Cape, during the first rainfall event of the wet season. Water S A 27: 65-70.

SNYMAN, R.G. 2000. Cellular biomarkers of exposure to the fungicide copper oxychloride in the common garden snail Helix aspersa in Western Cape vineyards. Ph.D. thesis, Stellenbosch University, Stellenbosch.

SNYMAN, R.G., REINECKE, S.A. \& REINECKE, A.J. 2000. Hemocytic lysosome response in the snail, Helix aspersa, after exposure to the fungicide copper oxychloride. Archives of Environmental Contamination and Toxicology 39:480-485.

STEENKAMP, V.E., DU PREEZ, H.H. \& SCHOONBEE, H.J. 1994. Bioaccumulation of copper in the tissues of Potamonautes warreni (Calman) (Crustacea, Decapoda, Brachyura) from industrial, mine and sewage-polluted freshwater ecosystems. South African Journal of Zoology 29: 152-161.

US GEOLOGICAL SURVEY 1982. The role of sediments in the chemistry of aquatic systems. In: Proceedings of the Sediment Chemistry Workshop, (eds) L. Bradford \& A.J. Horwitz, No. 969, pp. 1-6. Department of the Interior, Denver.

VAN EEDEN, P.H. \& SCHOONBEE, H.J. 1991. Bioaccumulation of heavy metals by the freshwater crab Potamonautes warreni from a polluted wetland. South African Journal of Wildlife Research 21: 103-108.

VAN STRAALEN, N.M. \& VERKLEIJ, J.A.C. 1993. Leerboek Oecotoxicologie. V.U. Uitgeverij, Amsterdam.

WATER RESEARCH COMMISSION 1999. Quality of Domestic Water Supplies. Vol. 1: Assessment Guide. Water Research Commission, Department of Water Affairs and Forestry, Department of Health, Pretoria.

WATLING, R.J. \& WATLING, H.R. 1983. Metal surveys in South African estuaries. VII. Bushmans, Kariega, Kowie and Great Fish Rivers. Water SA 9: 66-70. 